\title{
Effect of Intercropping of Frenchbean on Growth, Yield and Quality Parameters of Capsicum. (Capsicum frutescens $L_{\text {.) }}$ var Nishat-1
}

\author{
M. Mudasir Magray*, K. Hussain, Ajaz Ah. Malik, Rizwan Rashid and Gazala Nazir
}

Division of Vegetable Science Sher-e-Kashmir University of Agricultural Sciences and Technology of Kashmir, India

*Corresponding author

\section{A B S T R A C T}

Ke y w or d s
French bean,
Intercropping,
Capsicum, yield,
and Quality

The present investigation was conducted during year Kharif 2018 and Kharief 2019 at experimental field of Division of Vegetable Sciences, SKUAST-Kashmir to assess the response of growth, yield and quality of capsicum (capsicum frutescence L.) var Nishat-1 with intercropping of frenchbean under temperate conditions of Kashmir valley. It was found that intercropping of Frenchbean has improved various growth, yield and quality parameters of Capsicum. Pooled result of two years (Kharief-2018 and Kharief-2019) revealed that treatment $T_{2}$ ( 1 line of French bean:2 lines of Capsicum) recorded maximum values of plant height $(61.67 \mathrm{~cm})$, no of secondary branches plant ${ }^{-1}(7.94)$, plant spread $(40.71 \mathrm{cms})$, no. of fruit plant $^{-1}(12.74)$, average fruit weight $(80.91 \mathrm{gms})$, fruit Length $\left(7.35 \mathrm{~cm}\right.$ ), fruit diameter $(7.33 \mathrm{~cm})$, fruit yield plant ${ }^{-1}\left(206.62 \mathrm{q} \mathrm{ha}^{-1}\right)$, T.S.S Brix ${ }^{0}(4.91)$,

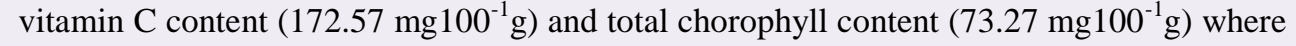
the values were significant in most of the parameters showing beneficial effect of intercrop.

\section{Introduction}

Capsicum (Capsicum annuum L.) also known as sweet pepper or bell pepper is one of the most popular vegetable crops grown in India as well as in several other parts of the world. It is believed to be the native of tropical South America (Shoemaker and Tesky, 1995). In India, capsicum occupies an area of 24,000 hectares with an estimated production of 33,000 metric tones. (NHB, 2016-17). The productivity of capsicum is very low in India. Capsicum under open field cultivation yields between 2040 tha $^{-1}$, where as in a greenhouse the yield ranges from 100 to 120 t/ha. Bell pepper (Capsicum аппиит) is among the most grown vegetables in greenhouses worldwide. From a nutritional prospective, bell pepper is rich in vitamins; chiefly, Vitamin $\mathrm{C}$ and provitamin $\mathrm{A}$. Concentrations of vitamin $\mathrm{C}$ is ranged from 63 to $243\left(\mathrm{mg} 100 \mathrm{~g}^{-1}\right)$ depending on fruit colour (Howard et al., 1994). In a survey on content of vitamin $\mathrm{C}$ in fruits and vegetables, bell peppers represented the highest fourth out of 42 choices (Frank et al., 2001). A $100 \mathrm{~g}$ of edible portion of pepper provides $24 \mathrm{Kcal}$ of energy, $1.3 \mathrm{~g}$ of protein, $4.3 \mathrm{~g}$ of carbohydrates and $0.3 \mathrm{~g}$ of fat (Zende, 2008). 
Also, it is one of the valuable medicinal plants in pharmaceutical industries, owing to high amounts of health promoting substances, particularly antioxidant, capsaicin and capsanthin (Aminifard et al., 2012). Greenhouse bell pepper cultivars are hybrids that have bellshaped or blocky-type fruits with varied colors. While green is the most favored color in bell peppers, red and yellow are also preferred with higher price in fresh market. Market shares in USA are about $80 \%$, $10 \%$, and $8 \%$ for the three colors, respectively (Frank et al., 2001). Such hybrid cultivars are characterized for high productivity and quality traits. The farmers generally prefer the intercropping system because it produces higher total crop yield area $^{-1}$, provides insurance against total crop failure, and also reduces incidences of pests and diseases (Lyocks et al., 2013). The advantages of intercropping are risk minimization, effective use of available resources, efficient use of labour, increased crop productivity, erosion control and food security (Addo-quaye et al., 2011). Yield advantage occurs because growth resources such as light, water, and nutrients are more completely absorbed and converted to crop biomass by the intercrop over time and space as a result of differences in competitive ability for growth resources between the component crops, which exploit the variation of the mixed crops in characteristics such as rates of canopy development, final canopy size (width and height), photosynthetic adaptation of canopies to irradiance conditions, and rooting depth Careful planning is required when selecting the component crops of a mixture, taking into account the environmental conditions of an area and the available crops or varieties. It was shown by many researchers that intercropping of different vegetable crops provided important advantages as well as higher profitability than vegetables grown as sole crops (Nursima, 2009).Moreover, because inorganic fertilizers have contributed to environmental damage such as nitrate pollution, legumes grown in intercropping are regarded as an alternative and sustainable way of introducing $\mathrm{N}$ into lower input agro ecosystems (Fustec et al., 2010).

\section{Materials and Methods}

A field experiment was carried out at experimental field Division of Vegetable Sciences, SKUAST-Kashmir during Kharief 2018 and Kharief 2019 laid out in Randomized Block Design with three replications. The experiment was laid out in RBD design with 6 treatments replicated thrice. The Capsicum seeds were sown in poly house during April and transplanted at a distance of $60 \times 45 \mathrm{~cm}$ during May in open conditions. French was sown directly in fields during the last week of may. Treatments include $\mathrm{T}_{1}=1: 1, \mathrm{~T}_{2}=1: 2, \mathrm{~T}_{3}=1: 3, \mathrm{~T}_{4}=1: 4$, $\mathrm{T}_{5}=1: 5$ and $\mathrm{T}_{6}=($ Sole sowing of Capsicum $)$. Recommended dose of fertilizers were applied as per recommended packages of practices of SKUAST-KASHMIR for both crops in the form of urea, diammonium phosphate and muriate of potash, respectively along with 20 tonnes of FYM. Before final land preparation, $50 \%$ of nitrogen and entire quantity of phosphorus and potash were applied as basal dos. The plant protection measures were taken up to control pest and diseases as and when required along with intercultural operations. In each plot 10 plants were tagged for taking all observations. Harvesting of capsicum was done in pickings. Plant height was recorded at final pickings in cms with the help of measuring scale Fruit parameters were taken after harvesting. Number of secondary branches was taken during full vegetative stage. Plant spread was measured with the help of measuring sacle. Number of fruits per plant were calculated by adding total number of fruits in each picking. Average fruit weight (gms) was taken on weighing balance and taken on average of 10 
tagged plants. Fruit length and fruit diameter were taken with the help of vernier caliper in centimetres. Total fruit yield was taken on plot basis and then converted into quintals per hectare. Chemical analysis was done using the standard procedures.T.S.S ${ }^{0}$ Brix was recorded with Digital Refractometers, Ascorbic acid $\left(\mathrm{mg} 100 \mathrm{~g}^{-1}\right)$ content of clove from each treatment was determined by 2,6 dichlorophenol indophenols visual titration method suggested by A.O.A.C (1975) and expressed in milligram per $100 \mathrm{~g}$ of fresh weight for all the treatment combinations in all replications. Total chlorophyll was estimated using procedure of Lorenzen. C. J. 1967. Data recorded was tabulated, pooled and statistically analysed as per Gomez and Gomez, 1984 Significant difference between treatment means was tested through ' $F$ ' test and critical difference (CD) was worked out wherever ' $F$ ' value was found to be significant for treatment effect.

\section{Results and Discussion}

Effect of intercropping on growth, yield and quality of capsicum

As per tables -(1) pooled data of two years kharief-2018 and kharief-2019 revealed that treatment $\mathrm{T}_{2}$ (2 capsicum lines: 1 french bean line) recorded maximum values of plant height, $(61.67 \mathrm{~cm})$, no. of secondary branches plant $^{-1} \quad$ (7.94),plant spread $(40.71 \mathrm{~cm})$ followed by treatment $\mathrm{T}_{3} \quad$ (3capsicum lines:1frenchbean line) which was significantly superior to all treatments in case of plant height and plant spread but at par with treatment $\mathrm{T}_{3} \quad$ (3 capsicum lines:1frenchbean line) in case of no. of secondary branches per plant ${ }^{-1}$ (table-1).

From table-2 it was depicted that treatment $\mathrm{T}_{2}$ (2 capsicum lines:1 french bean line) maximum values of number of fruits plant ${ }^{-1}$ (12.74), average fruit weight (80.91), fruit length $(7.35 \mathrm{~cm})$, fruit diameter $(7.33 \mathrm{~cm})$ and fruit yield (206.62 q ha ${ }^{-1}$ followed by treatment $\mathrm{T}_{3}$ (3 capsicum lines:1frenchbean line) where the values were significantly superior to all other treatments in case of fruit length, fruit diameter, fruit yield per hectare but at par to treatments $\mathrm{T}_{1}, \mathrm{~T}_{3}$ in case of no. of fruits per hectare, and to treatment $\mathrm{T}_{3}$ in case of average fruit weight (table -2).

From table-3 it was revealed that treatment $\mathrm{T}_{2}$ ( 2 capsicum lines: 1 french bean line) recorded maximum values of quality parameters viz., T.S.S. (4.91)Brix ${ }^{0}$, Vitamin C content (172.57 $\left.\mathrm{mg} 100^{-1} \mathrm{~g}\right)$ and chorophyll content $(73.27 \mathrm{mg}$ $100^{-1} \mathrm{~g}$ ) followed by treatment $\mathrm{T}_{3}(3$ capsicum lines:1frenchbean line) which was significantly superior to all other treatments in case of vitamin $\mathrm{c}$ content but at par with treatment $\mathrm{T}_{2}, \mathrm{~T}_{3}, \mathrm{~T}_{4}, \mathrm{~T}_{5}$, and $\mathrm{T}_{6}$ in case of T.S.S.(Brix) ${ }^{0}$ and to treatment $\mathrm{T}_{3}$ and $\mathrm{T}_{6}$ in case of chlorophyll content (table -3 ).

Table.1 Influence of intercropping effect of Frenchbean on growth parameters of capsicum

\begin{tabular}{|l|c|c|c|}
\hline Treatment details & $\begin{array}{c}\text { Plant Height } \\
\text { cms }\end{array}$ & $\begin{array}{c}\text { No. of Secondary } \\
\text { branches }\end{array}$ & $\begin{array}{c}\text { Plant Spread } \\
\text { cms }\end{array}$ \\
\hline $\mathbf{T}_{\mathbf{1}}=\mathbf{1 : 1}$ & 52.53 & 6.88 & 36.68 \\
\hline $\mathbf{T}_{\mathbf{2}}=\mathbf{2 : 1}$ & $\mathbf{6 1 . 6 7}$ & $\mathbf{7 . 9 4}$ & $\mathbf{4 0 . 7 1}$ \\
\hline $\mathbf{T}_{\mathbf{3}}=\mathbf{3 : 1}$ & 54.78 & 7.71 & 37.35 \\
\hline $\mathbf{T}_{\mathbf{4}}=\mathbf{4 : 1}$ & 50.94 & 6.67 & 33.87 \\
\hline $\mathbf{T}_{\mathbf{5}}=\mathbf{5 : 1}$ & 47.18 & 6.87 & 33.84 \\
\hline $\mathbf{T}_{\mathbf{6}}=\mathbf{( S o l e ~ s o w i n g ~ o f ~ C a p s i c u m ) ~}$ & 50.09 & 6.76 & 36.00 \\
\hline $\mathbf{C . D} \leq \mathbf{0 . 5}$ & 3.77 & 0.40 & 2.61 \\
\hline
\end{tabular}


Table.2 Influence of intercropping effect of Frenchbean on fruit yield and yield attributes of capsicum

\begin{tabular}{|c|c|c|c|c|c|}
\hline Treatment details & $\begin{array}{l}\text { No. of Fruits } \\
\text { Plant }^{-1}\end{array}$ & $\begin{array}{l}\text { Average Fruit } \\
\text { Weight (gms) }\end{array}$ & $\begin{array}{l}\text { Fruit Length } \\
\text { (cm) }\end{array}$ & $\begin{array}{c}\text { Fruit Diameter } \\
(\mathbf{c m})\end{array}$ & $\begin{array}{l}\text { Fruit Yield } \\
\qquad \mathrm{q} \mathrm{ha}^{-1}\end{array}$ \\
\hline$T_{1}=1: 1$ & 12.13 & 74.37 & 6.17 & 6.21 & 177.10 \\
\hline$T_{2}=2: 1$ & 12.74 & 80.91 & 7.35 & 7.33 & 206.62 \\
\hline$T_{3}=3: 1$ & 12.53 & 77.78 & 6.97 & 6.87 & 187.33 \\
\hline$T_{4}=4: 1$ & 10.32 & 75.50 & 6.91 & 6.87 & 178.27 \\
\hline$T_{5}=5: 1$ & 10.52 & 71.04 & 6.79 & 6.85 & 179.05 \\
\hline $\begin{array}{l}T_{6}=(\text { Sole sowing of } \\
\text { Capsicum) }\end{array}$ & 10.66 & 74.50 & 6.60 & 6.45 & 188.95 \\
\hline C.D $\leq .0 .5$ & 1.24 & 4.55 & 0.37 & 0.38 & 7.82 \\
\hline
\end{tabular}

Table.3 Influence of intercropping effect of Frenchbean on quality parameters of capsicum

\begin{tabular}{|c|c|c|c|}
\hline Treatment Details & T.S.S Brix ${ }^{0}$ & $\begin{array}{l}\text { Vitamin C } \\
{\operatorname{mg} 100^{-1} \mathrm{~g}}^{-}\end{array}$ & $\begin{array}{l}\text { Total Chorophyll } \\
\operatorname{mg100}^{-1} \mathrm{~g}\end{array}$ \\
\hline $\mathrm{T}_{1}=1: 1$ & 4.26 & 155.00 & 67.81 \\
\hline$T_{2}=2: 1$ & 4.91 & 172.57 & 73.27 \\
\hline $\mathbf{T}_{3}=3: 1$ & 4.80 & 162.25 & 70.42 \\
\hline$T_{4}=4: 1$ & 4.73 & 155.46 & 68.23 \\
\hline$T_{5}=5: 1$ & 4.56 & 149.27 & 68.56 \\
\hline $\mathrm{T}_{6}=($ Sole sowing of Capsicum $)$ & 4.65 & 148.04 & 69.62 \\
\hline C.D $\leq .0 .5$ & 0.36 & 7.27 & 4.21 \\
\hline
\end{tabular}

The higher values of growth, yield and quality parameters with treatment $T_{2}$ as compared to all other treatment including $\mathrm{T}_{6}$ treatment (sole sowing of capsicum) could be due to the competition between chilli and frenchbean for resources is much less probably because chilli is a transplanted crop and frenchbean is a direct sown crop. Similar results were reported by Olasantan (1991). Nutrient uptake of pure crop of chilli was 30, 27 and 21 per cent less than the respective $\mathrm{N}, \mathrm{P}$ and $\mathrm{K}$ uptake by intercropped chilli in chilli-french bean system. Similar reports were given by M.A.Abd EL-Gaid et al., (2014) in tomato. Similar reports were found in different vegetable crops by Shen and Chu 2004., Javanmard et al., 2009, Dharmar deh et al., 2010, Addo-Quaye et al., 2011) and also by P. Choudhuri and J. C. Jana 2016 in okra reported same results. Positive effects of legumes on other vegetable crops could be due to nitrogen fixing ability of legumes.

\section{References}

A.O.A.C (Association of Official Analytical Chemist) 1994. Official Method of Analysis. $12^{\text {th }}$ Ed. Washington, DC.

Addo-Quaye, A.A., Darkwa, A.A., Ocloo, G.K., 2011. Yield and productivity of 
component crops in a maize-soybean intercropping system as affected by time of planting and spatial arrangement. ARPN Journal of Agricultural and 839 International Journal of Bio-resource and Stress Management 2016, 7(4):837-840 (C) 2016 PP House Biological Science 6, $50-57$.

Aminifard M.H., Aroiee H., Ameri A., Fatemi H., (2012). Effect of plant density and nitrogen fertilizer on growth, yield and fruit quality of sweet pepper (Capsicum annuum L.). Afr J Agric Res. 7(6): 859866.

Annonymous, 2016-17. National Horticulture Board, Area and Production of Vegetables for the year 2016-2017.

Dahmardeh,M.A.Ghanbari,B.A Sayasar and M.Ramrodi 2010.The role of intercropping maize (Zea mays L.) and Cow pea (Vigna Unguiculata L.) on yield and soil chemical properties.African Journal of Research 5.631-636.

Frank CA, Robert GN, Eric HS, Bridget KB, Amarat HS (2001) Consumer preferences for color, price, and vitamin C content of bell peppers. Hort Sci. 36(4):795-800.

Fustec, J., Lesuffleur, F., Mahieu, S., Cliquet, J.B., 2010. Nitrogen rhizodeposition of legumes-a review. Agronomy for Sustainable Development 30, 57-66.

Gomez, K.A. and Gomez, A.A. 1984. Statistical procedures for agriculture research. Second Ed. Wiley Interscience Publication John Willey and Sons, New York.

Howard LR, Smith RT, Wasner AB, Villalon B, Burns EE (1994) Provitamin A and ascorbic acid content of fresh pepper cultivars (Capsicum annuum) and processed jalapenos. J Food Sci. 59: 362-365.
Javanmard, A. A.D. M. Naseeb, A.Javanshir, M. Moghaddam and H. Janmohammadi, 2009. Forage yield and quality in intercropping of maize with different legumes as doubled -cropped J.Food Agric Environ,7: 163-166.

Lorenzen. C. J., (1967). Determination of chlorophyll and pheopigments: Spectrophotometric equations. Limnol. Oceanogr. 12: 343-346.

Lyocks, S.W.J., Tanimu, J., Dauji, L.Z., 2013. Growth and yield parameters of ginger as influenced by varying populations of maize intercrop. Journal of Agricultural Crop Research 1, 24-29.

M.A.Abd El-Gaid,M.H Al-Dokeshy and Dalia,M.T.Nassef.201.Effect of intercropping system of tomato and common bean on growth,yield components and land equivalent ratio in new valley Governorate.Asian Journal of crop science 6(3)-254-261.

Nursima, K.A., 2009. Profitability of intercropping corn with mungbean and peanut, USM. R\&D Journal 17, 65-70.

P. Choudhuril and J. C. Jana. 2016 Intercropping in Okra for Sustainable Vegetable Production International Journal of Bio-resource and Stress Management, 7(4):837-840.

Shen.Q and G.Chu.2004.Bidirectional nitrogen transfer in an intercropping system of peanut with rice cultivated in aerobic soil.Biol.Fertil. Soils,40:80-81.

Shoemaker, J.S. and Tesky, B.K.E. (1995). Practical Horticulture, John Wiley and Ions. Inc., New York.

Zende U.M.,(2008). Investigation on production techniques in capsicum under protected cultivation. M.Sc. degree. College of Agriculture, Dharwad, University of Agricultural Sci., Dharwad. 


\section{How to cite this article:}

Mudasir Magray, M., K. Hussain, Ajaz Ah. Malik, Rizwan Rashid and Gazala Nazir. 2021. Effect of Intercropping of Frenchbean on Growth, Yield and Quality Parameters of Capsicum. (Capsicum frutescens L.) var Nishat-1. Int.J.Curr.Microbiol.App.Sci. 10(01): 3019-3023. doi: https://doi.org/10.20546/ijcmas.2021.1001.350 